\title{
Research on the Development Strategy of "Double Qualified" English Teachers in Application-oriented Universities
}

\author{
Zhao Weihong ${ }^{1, \mathrm{a}}, \mathrm{Xu}_{\text {Daoping }}{ }^{1, \mathrm{~b}}$, Shen Hongwei ${ }^{1, \mathrm{c}}$ \\ ${ }^{1}$ Qingdao Huanghai University \\ Qingdao, China \\ a707848150@qq.com, b194430179@qq.com, JJeremy8181@163.com
}

\begin{abstract}
The professional teachers in the undergraduate school should not only have the basic ability and quality of teachers, but also have rich modern knowledge and practical ability. Based on the analysis and research of the main problems faced by dual teachers, the corresponding solutions are put forward. It can be known that in the study of its own resources, professional development, teaching, reflection, learning, research and cooperation is the core elements, of which five factors affect each other. As a result, teachers should define the main goal of teaching that is to enable students to improve the ability of language application, and highlight the practicality of the teaching content and pertinence. In view of the characteristics of English education, the necessity of teacher development is obtained. The promotion program is put forward to enhance the ability of teachers, respectively from school, students and social aspects of research. It can provide a strong evidence that the development strategy has great significant for the English teachers.
\end{abstract}

Keywords-English teachers; Development strategy; Promotion program; Improvement

\section{INTRODUCTION}

English belongs to a kind of comprehensive teaching course. Objectively speaking, it is difficult to teach. English is the most popular and common language, therefore, this course has instrumental characteristics all over the world. English is quite widely used for a long time. More than $70 \%$ of the world's mail is written in English and more than $70 \%$ of the world's scientific publications are published in English. It includes not only the teaching focus on grammar and vocabulary, but also need to cultivate students' humanistic qualities, thinking, social communication ability excuse.

As China continues to open to the outside world, the continuous progress of science and technology, improvement of international status, the urgent need for a large number of professionals proficient in foreign languages, make China play a more active role in international affairs. The college stage is the knowledge learning of college students in life, at the field of scientific research, improve the humanistic quality of the excellent individual period, they need extensive worldwide communication, multi-channel access to knowledge and information.

\section{THE MAIN PROBLEMS OF "DUAL QUALIFIED" ENGLISH TEACHERS}

\section{A. Development flaw of knowledge system}

The teacher education system of our country is not perfect, the current college English teachers are university graduates, most teachers before graduation only received basic computer knowledge, has not learned the information literacy course specialized (a few newly graduated teachers even haven't heard a word, information literacy) so the overall information literacy is weak. The Ministry of education required by the pre job training of university teachers is the provincial organization teacher qualification exam training, content is not complete, only to open higher education occupation moral cultivation, introduction to higher education psychology and regulations of higher education and university teachers, without specialized courses education in Information Science, unable to effectively cultivate and enhance their information literacy [1].

In order to improve the information behavior of college teachers, we must take advanced educational theory as the guidance. The teaching of information science research in the field of education is the teaching of information education in the teaching of the status, role and value, reveal the education information application rules, principles, methods and ways of science, only the teaching of information education in university teachers training in the teaching plan, through the teaching of information theory knowledge and learning, in order to make the university teachers to change educational ideas, in the mind really attach great importance to the cultivation of its effectiveness and improve information behavior [2-4].

\section{B. Training measures lack effectiveness}

Although in recent years, the city university is also promoting the construction of campus information, strengthen the modern teaching facilities and the implementation of a variety of training programs, some English teachers use the multimedia teaching means vivid, make the original lectures more can attract the attention of students, easy to understand and accept. But according to the interview, the College 
English teachers in the teaching process, teaching mode is still followed the traditional teaching mode, does not change the mode of teaching activities with the teacher as the center, the teacher is still dominated in the classroom, students are still largely passive; teachers' teaching is still individual behavior between teachers and teachers' teaching communication is not so smooth and more deeply, also not to be able to achieve the integration of course and technology.

\section{The teacher lacks the ability to improve information}

Quick training just let the teacher at the time and enjoy the benefits of information technology, but the lack of practice opportunities but cannot allow teachers to master the knowledge into ability. In practice, lack of mutual aid and cooperation is more important. The enthusiasm of teachers for using information technology and collecting information resources. Therefore, it is very important for teachers to master information technology knowledge and improve their information ability after the training practice and the mutual aid and cooperation in practice.

\section{THE DEVELOPMENT STRATEGY SIGNIFICANCE}

\section{A. Teachers can raise awareness}

Teachers need to improve their understanding of the importance of on-the-job training and the orientation of local institutions of higher learning. First, teachers need to improve their understanding of the importance of participating in onthe-job training activities. In-service training activities on the current construction of College Teachers' professional development, restructuring and development of local colleges and the modern occupation education system plays an important role, to improve the practical significance the current development predicament of local colleges. Second, teachers need to know the orientation of local universities. At present, the existing teachers of local universities in Shandong province are not accurate in their understanding of the location of local colleges and universities [5,6]. They fail to realize the changes in the quality and ability of teachers in the transformation and development of universities and colleges. The concept of academic orientation which requires teachers to change the existing colleges of local colleges and universities, the establishment of application oriented university thought, to realize the target of training applied technical talents, and the corresponding changes of the requirements of teachers, teachers should meet the requirements in the theoretical knowledge and practical ability of both.

Teachers in local universities can choose in-service training activities that can compensate for their lack of ability, according to the education situation received in the pre service education stage and the existing experience of the post. For example, did not accept the normal education for teachers, can choose to study abroad, visiting and on-the-job training, to strengthen the theoretical knowledge, enhance their ability of scientific research; the lack of practical skills of teachers, can choose to visit enterprises and training room and practice training activities, enhance the practice operation skill training.

\section{B. Promote the construction of Teachers}

The universities and colleges should cooperate with each other, combine schools with universities and schools. The development of institutions of higher learning requires the adjustment of the school in personnel training, faculty construction, curriculum construction, etc., and should strengthen cooperation with other units in the construction of teachers [7]. We are on the strategy of the construction of teachers in local colleges training activities from the double perspective, there will be teachers as the future direction of development of university teachers in, through training activities, teachers guide undergraduate colleges for double qualified teachers, therefore, schools should strengthen cooperation and build a multi.

The current emphasis on in-service training to improve teachers' theoretical knowledge literacy, strengthen the teachers' scientific research ability, neglect of teachers in local universities also need to improve the practical needs of practical skills, thus to enrich the content of on-the-job training, improve the dual theory and practice. With the rise of occupation colleges in recent years, more and more social concern for such institutions, it not only has some social constantly cultivate professional knowledge, talents and technology ability, occupation education pay more attention to the training of students' practical ability, this is undoubtedly the market demand for such students increase, so English ability of students occupation colleges imminent, which helps them to better employment, participate in social competition.

\section{STUDY OF ENGLISH TEACHER PROMOTION PROGRAM}

The training object of in-service training of undergraduate teachers based on dual teacher type is teachers, and teachers have fulfilled their responsibilities in education and teaching since graduation, and have a firsthand experience in education and teaching work. In the course of on-the-job training, the study of theoretical knowledge and the training of a certain skill can make the teacher have some experience on the basis of the existing experience and get a solution to the problem of education and teaching. Teachers learn through on-the-job training, solutions can be obtained in the dilemma of occupation development, help teachers in the future teaching work, to better cope with such problems, improve teachers' education level.

In the study of its own resources, professional development, teaching, reflection, learning, research and cooperation is the core elements of the main, interlocking, these five factors affect each other, complement each other, throughout the entire occupation career of teachers, teaching is the priority among priorities, teachers in learning to reflect, learning how to learn and study teaching, also learn to cooperate, and reflection, learning, research and cooperation will be in different aspects in different degree to promote teachers' teaching. The best way for teachers to combine teaching and research to promote their professional development is to implement action research in teaching. The best combination of teaching and reflection is reflective teaching. As a professional teacher with better professional theory and complex professional skills, the growth and 
maturity of teachers need a gradual process of development. Therefore, as with all the teachers' development, with its own resources for teachers' professional development will have a stage, generally can be divided into initial stage, exploration stage, stable development period, rapid development period, stable period of development.

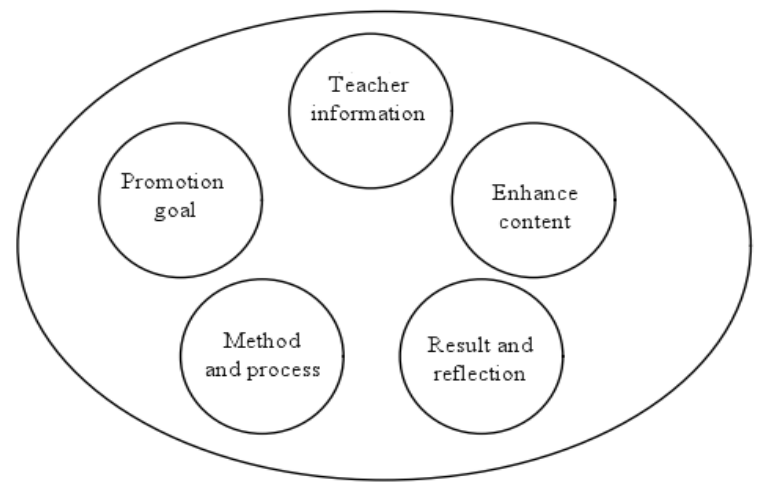

Fig. 1 English teacher promotion strategy

\section{A. The promotion strategy of school}

In terms of teaching conditions, schools need to increase capital investment in the allocation of teaching equipment and infrastructure construction, and build the necessary language rooms, computer rooms and multi-media classrooms. And a part of the cost for daily operation and maintenance speech classroom, multi-media classroom, equipment maintenance, to ensure that it is always in good working state, to provide the necessary support for English teaching. Install a school FM station that allows students to listen to English radio and English recordings. To set up special management FM, in the afternoon and evening time of extracurricular activities for students on the tape after class so that students can have more opportunities to listen to English, learn to create a language learning context environment, so as to enable students to develop the habit of listening English. At the same time, schools should organize English teachers, arrange more extracurricular activities, and help students create a good atmosphere and environment for English learning.

Send some excellent teachers to study in foreign universities, attend academic conferences, short-term training, teaching seminars, etc., and provide teachers with opportunities for education after their posts. In this way, not only can we draw on the advanced teaching experience of domestic and foreign counterparts, but also bring a lot of advanced teaching ideas. At the same time, it is also helpful to improve the quality and ability of teachers. After returning home, the school should organize overseas personnel to do the exchange of experience reports, and learn the new ideas and communicate with other teachers to communicate and benefit more people.

Make an effort to create a platform for academic exchanges between teachers and students. The industry renowned experts and scholars are regularly invited to the school to carry out academic exchanges, so that teachers can have the opportunity to receive the forefront of relatively new, industry information timely, understand the social demand for talents, and make timely adjustments to the way of teaching, to cultivate qualified talents for the real needs of enterprises [8].

\section{B. The promotion strategy of curriculum reform}

The curriculum system cannot adapt to the English Practical English teaching requirements, curriculum rigid, teaching material and students learning divorced from real life, not the actual use, and the general liberal arts, cannot meet the different language levels, different students learning needs, which affects the development of English teaching to a great extent. Therefore, it is very important for schools to rebuild the English curriculum system in Vocational schools.

The compulsory course on the basis of current college English curriculum, mainly divided into said courses, reading writing and translation courses and small oral English course for network audio-visual; improve the elective courses refers to the English language skills training courses, including advanced listening, advanced writing, practical translation, advanced reading, newspaper reading, foreign trade correspondence courses; optional course to the quality of education, focusing on the students' cultural knowledge and comprehensively improving the quality of humanities, the main courses include western culture, film appreciation, intercultural communication course. In addition, we should also consider the combination of English learning and specialized English learning.

\section{The promotion strategy of English teachers}

Teachers should define the main goal of teaching is to enable students to improve the ability of language application, highlighting the practicality of the teaching content and pertinence, the basic ability of languages and the actual foreign competence and communicative ability training combined, should pay attention to cultivating students' listening, speaking, reading, writing and translating English Comprehensive ability in practice in the teaching, especially to increase the skill of listening especially practical communicative ability training, the training must use oral communicative ability as an important task, verbal communication is simple to adapt to foreign activities and business activities in need. The teacher in the classroom usually pay attention to creating language environment, as far as possible to find more opportunities to give students a broader space to practice listening and speaking ability, such as students, let students listen to English tapes, watch English films and videos to master English idiomatic expressions, but also can make full use of teaching materials and activities the advantage of multimedia to create imaginary English environment. The creation of English environment is not only in the classroom, but also in the creation [9].

In the English teaching process, we should pay attention to strengthen the talk with the students and often emotional communication, using the opportunity to further understand every one of the students, especially the students who are not interested in English, they learn English in the emotional needs, to help them recognize and eliminate negative influence from the outside world, self-learn to adjust the mentality [10]. 
For example, in the classroom, we should encourage more students who do not speak English, even if they can only read a word, we should give certain, in order to eliminate their nervousness and fear. As the training of high skilled personnel, College English teachers should not only pay attention to professional knowledge and basic skills training, but also through the cultivation of noble political quality and good moral quality in teaching. The most obvious embodiment of teachers' Ideological and moral quality in teaching is the professionalism of teachers and their love for students.

\section{CONCLUSION}

With the study of "Research on the Development Strategy of "Double Qualified" it can be known that the college English teachers in the teaching process, teaching mode is still followed the traditional teaching mode, does not change the mode of teaching activities with the teacher as the center. As a result, the teachers should define the main goal of teaching is to enable students to improve the ability of language application, highlighting the practicality of the teaching content and pertinence. The paper analyzes and studies the main problems faced by teachers, and studies the school, the students and the society, and puts forward the promotion program to improve teachers' abilities.

\section{REFERENCES}

[1] Wang X F, Davies M, Liu G H. "A Good Platform for English Teachers and Learners:the Corpus of Contemporary American English(COCA)". Computer-Assisted Foreign Language Education in China, 2008, pp.215-218.

[2] Medgyes P. Nonnative. "Speaker English Teachers: Research, Pedagogy, and Professional Growth”. ELT Journal, 2011, pp.210-212.

[3] Negretti R, Kuteeva M. "Fostering metacognitive genre awareness in L2 academic reading and writing: A case study of pre-service English teachers". Journal of Second Language Writing, 2011, pp.95-110.

[4] Noomura S. "English-Teaching Problems in Thailand and Thai Teachers' Professional Development Needs". English Language Teaching, 2013, pp.12-18.

[5] Shin S K. "It Cannot Be Done Alone": The Socialization of Novice English Teachers in South Korea". Tesol Quarterly, 2012, pp.542-567.

[6] Topkaya E Z, Uztosun M S. "Choosing Teaching as a Career: Motivations of Pre-service English Teachers in Turkey," Journal of Language Teaching \& Research, 2012, pp.126-134.

[7] Wati H. "The Effectiveness of Indonesian English Teachers Training Programs in Improving Confidence and Motivation," International Journal of Instruction, 2011,pp.79-104.

[8] Sumru Akcan, Sibel Tatar. “An investigation of the nature of feedback given to pre - service English teachers during their practice teaching experience," Teacher Development, 2010, pp.153-172.

[9] Marie-José Guilloteaux. "Motivational strategies for the language classroom: Perceptions of Korean secondary school English teachers," System, 2013, pp.3-14.

[10] Trent J. "The Discursive Positioning of Teachers: Native-Speaking English Teachers and Educational Discourse in Hong Kong," Tesol Quarterly, 2012, pp.104-126. 